Thapsi gar gi $n$ - i nduced ER st ress suppr essi ve compounds from the mishr oom Mcol ept odonoi des ai t chi soni $\mathrm{i}$

\begin{tabular}{|l|l|}
\hline 著者 & $\begin{array}{l}\text { Choi Jae- Hoon, Suzuki Tomohi ro, Okumur a } \\
\text { H r oshi, Nagai Kaor u, H r ai H r of um , } \\
\text { Kawagi shi H r okazu }\end{array}$ \\
\hline $\begin{array}{l}\text { j our nal or } \\
\text { publ i cat i on ti t l e }\end{array}$ & Tet r ahedr on I et ter s \\
\hline vol une & 56 \\
\hline nunber & 41 \\
\hline page r ange & $5561-5563$ \\
\hline year & $2015-10-07$ \\
\hline 出版者 & El sevi er \\
\hline 権利 & ( C) 2015 El sevi er Lt d. Al I ri ght s r eserved. \\
\hline URL & ht t p: //hdl . handl e. net /10297/10376 \\
\hline
\end{tabular}




\section{Graphical Abstract}

Thapsigargin-induced ER stress suppressive compounds from the mushroom

Mycoleptodonoides aitchisonii

Jae-Hoon Choi, Tomohiro Suzuki, Hiroshi Okumura, Kaoru Nagai, Hirofumi Hirai, Hirokazu Kawagishi

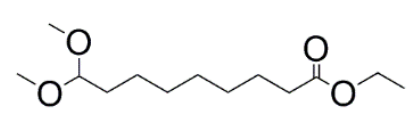

1<smiles>O[C@H]1CCO[C@@H]1Cc1ccccc1</smiles>

2<smiles>CC1=C(CO)C(=O)CC1O</smiles>

3<smiles>O=C1C=C(c2ccccc2)OCC1</smiles> 
Tetrahedron Letters

journal homepage: www.elsevier.com

\title{
Thapsigargin-induced ER stress suppressive compounds from the mushroom Mycoleptodonoides aitchisonii
}

\author{
Jae-Hoon Choi ${ }^{\mathrm{a}, \dagger}$, Tomohiro Suzuki ${ }^{\mathrm{b}, \dagger}$, Hiroshi Okumura ${ }^{\mathrm{a}}$, Kaoru Nagai ${ }^{\mathrm{d}}$, Hirofumi Hirai ${ }^{\mathrm{a}, \mathrm{c}}$, Hirokazu \\ Kawagishi ${ }^{\mathrm{a}, \mathrm{c}, *}$ \\ ${ }^{a}$ Graduate School of Agriculture, Shizuoka University, 836 Ohya, Suruga-ku, Shizuoka 422-8529, Japan \\ ${ }^{b}$ Center for Bioscience Research and Education, Utsunomiya University, 350 Mine-machi, Utsunomiya, Tochigi 321-8505, Japan \\ ${ }^{c}$ Research Institute of Green Science and Technology, Shizuoka University, 836 Ohya, Suruga-ku, Shizuoka 422-8529, Japan \\ ${ }^{d}$ Department of Nutrition, Koshien University, 10-1, Momijigaoka, Takaraduka, Hyogo 665-0006, Japan
}

\section{ARTICLE INFO}

\section{ABSTRACT}

\section{Article history:}

Received

Revised

Accepted

Available online

\section{Keywords:}

Mycoleptodonoides aitchisonii

Mushroom

Endoplasmic reticulum stress

Structure determination

Thapsigargin
Two novel compounds $\mathbf{1}$ and 2, along with two known ones (3 and 4) were isolated from the edible mushroom Mycoleptodonoides aitchisonii. The structures of 1-4 were determined and identified by interpreting their spectroscopic data. All the compounds showed protective activity against endoplasmic reticulum stress-dependent cell death.

2009 Elsevier Ltd. All rights reserved.
Endoplasmic reticulum (ER) is an important organelle for the synthesis, correct folding, post-translation modification and transport of nascent proteins to different destinies. ${ }^{1,2}$ ER stress is caused by disturbances in the structure and function of the ER with the accumulation of misfolded proteins and alterations in calcium homeostasis. In case of prolonged or aggravated ER stress, cellular signals leading to cell death are activated ${ }^{3}$. ER stress has been reported to cause not only neurodegenerative diseases $^{3-5}$ but also some other diseases, such as diabetes, atherosclerosis, or heart and liver disease. ${ }^{6}$

Therefore, protective activity against ER stress is possibly an important target for addressing these diseases, and the demand for new lead compounds prompted us to screen the protective activity of mushroom extracts. During the screening for ER stress protecting effects of the extracts of various mushrooms, we previously reported the protective compounds from the mushrooms Hericium erinaceus, ${ }^{7-9}$ Termitomyces titanicus, ${ }^{10}$ and Leccinum extremiorientale. ${ }^{11}$ Moreover, $\gamma$-lactones and phenylpentanols having protective activity against toxicity of tunicamycin (TM) or thapsigargin (TG) from the mushroom Mycoleptodonoides aitchisonii have been reported. ${ }^{12,13}$ In the course of our continuing search for ER stress protecting compounds from the mushroom $M$. aitchisonii, we found active compounds. We report here the isolation and structure determination of novel compounds (1 and 2), together with two known ones (3 and 4).

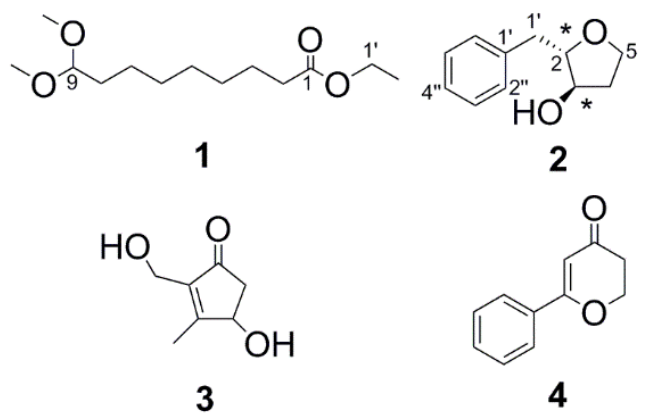

The fresh fruiting bodies of $M$. aitchisonii were extracted with $\mathrm{EtOH}$ and then with acetone. After the solutions had been combined and concentrated under reduced pressure, the concentrate was partitioned between $\mathrm{CH}_{2} \mathrm{Cl}_{2}$ and $\mathrm{H}_{2} \mathrm{O}$ and then between EtOAc and $\mathrm{H}_{2} \mathrm{O}$. Compounds 1, 3, and $\mathbf{4}$ were obtained

\footnotetext{
* Corresponding author. Tel.: +81-54-238-4885; fax: +81-54-238-4885; e-mail: kawagishi.hirokazu@shizuoka.ac.jp
}

${ }^{\dagger}$ These authors contributed equally to this work. 
from the $\mathrm{CH}_{2} \mathrm{Cl}_{2}$-soluble part and compound 2 was purified from the EtOAc-soluble part. ${ }^{14}$

Compound 1 was isolated as a colorless oil. The IR spectrum showed absorption bands at $2929 \mathrm{~cm}^{-1}$ and $1735 \mathrm{~cm}^{-1} .{ }^{15}$ Its molecular formula was determined as $\mathrm{C}_{13} \mathrm{H}_{26} \mathrm{O}_{4}$ by HRESIMS ( $\mathrm{m} / \mathrm{z} 269.1730[\mathrm{M}+\mathrm{Na}]^{+}$; calcd. for $\left.\mathrm{C}_{13} \mathrm{H}_{26} \mathrm{NaO}_{4}, 269.1729\right)$, indicating the presence of one degree of unsaturation in the molecule. The complete assignment of all the protons and carbons was accomplished by HMQC, COSY, and HMBC experiments as shown in Table 1 and Figure 1. The DEPT experiment and the molecular formula indicated the presence of three methyls, eight methylenes, a methine, and a quaternary carbon. The ethoxycarbonylpropyl moiety was elucidated by the COSY correlations (bold line in Fig. 1) and the HMBC correlations (H-1'/C-2', H-1'/C-1, H-2'/C-1', H-2/C-1, H-2/C-3, $\mathrm{H}-3 / \mathrm{C}-1, \mathrm{H}-3 / \mathrm{C}-2)$ and the chemical shift of $\mathrm{C}-1$ ( $\left.\delta_{\mathrm{C}} 173.8\right)$. The dimethoxypropanyl group was suggested by the NMR signals $\left[\delta_{\mathrm{H}}\right.$ $3.29(6 \mathrm{H}, \mathrm{s})$ and $\left.\delta_{\mathrm{C}} 52.6\right]$, the HMBC correlations [H-7/C-8, H7/C-9, H-8/C-7, H-8/C-9, H-9/C-7, H-9/C-8, H-9/MeO-, MeO/C-9], and the COSY correlations $(\mathrm{H}-7 / \mathrm{H}-8, \mathrm{H}-8 / \mathrm{H}-9)($ Fig. 1). The connection of the ethoxycarbonylpropyl, the dimethoxypropanyl and the other part was suggested by the molecular formula in $\mathbf{1}$. All the data allowed us to conclude that $\mathbf{1}$ was ethyl 9,9-dimethoxynonanoate.
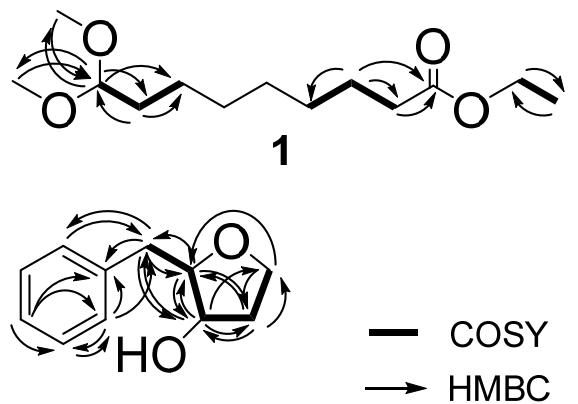

2

Figure 1. COSY and HMBC correlations of $\mathbf{1}$ and $\mathbf{2}$.

\begin{tabular}{|c|c|c|c|c|c|}
\hline \multicolumn{4}{|c|}{$1\left(\right.$ in $\left.\mathrm{CDCl}_{3}\right)$} & \multicolumn{2}{|c|}{2 (in $\left.\mathrm{CD}_{3} \mathrm{OD}\right)$} \\
\hline position & $\begin{array}{l}\delta_{\mathrm{H}} \\
\text { (mult., } J \text { in } \mathrm{Hz} \text { ) }\end{array}$ & $\delta_{C}$ & position & $\begin{array}{l}\delta_{\mathrm{H}} \\
\text { (mult., } J \text { in } \mathrm{Hz} \text { ) }\end{array}$ & $\delta$ \\
\hline 1 & & 173.8 & 1 & & \\
\hline 2 & $2.26(t, 7.4)$ & 34.4 & 2 & $3.64(\mathrm{~m})$ & 77.4 \\
\hline 3 & $1.58(\mathrm{~m})$ & 24.9 & 3 & $3.60(\mathrm{~m})$ & 73.2 \\
\hline \multirow[t]{2}{*}{$4,5,6$} & $1.29(\mathrm{~m})$ & $29.0,29.2$ & 4 & $1.66(\mathrm{~m}), 1.92(\mathrm{~m})$ & 36.1 \\
\hline & & 29.3 & 5 & $3.71(\mathrm{~m}), 3.77(\mathrm{~m})$ & 60.4 \\
\hline 7 & $1.29(\mathrm{~m})$ & 24.5 & $1^{\prime}$ & $2.61(\mathrm{dd}, 14.0,8.9)$ & 40.4 \\
\hline 8 & $1.55(\mathrm{~m})$ & 32.5 & & $2.97(\mathrm{dd}, 14.0,3.4)$ & \\
\hline 9 & $4.32(\mathrm{t}, 5.7)$ & 104.6 & $1^{\prime \prime}$ & & 140.9 \\
\hline $\mathrm{MeO}-9$ & $3.29(\mathrm{~s})$ & 52.6 & $2^{\prime \prime}, 6^{\prime \prime}$ & $7.24(\mathrm{~m})$ & 130.5 \\
\hline $1^{\prime}$ & $4.10(\mathrm{q}, 7.3)$ & 60.1 & $3^{\prime \prime}, 5^{\prime \prime}$ & $7.24(\mathrm{~m})$ & 129.2 \\
\hline $2^{\prime}$ & $1.23(\mathrm{t}, 7.3)$ & 14.2 & $4^{\prime \prime}$ & $7.16(\mathrm{~m})$ & 127.0 \\
\hline
\end{tabular}

Table 1. ${ }^{1} \mathrm{H}$ and ${ }^{13} \mathrm{C}$ NMR data for $\mathbf{1}$ and 2

Compound 2 was isolated as a colorless crystal showing a specific rotation of $[\alpha]_{\mathrm{D}}^{28}+15\left(\mathrm{c} 0.25, \mathrm{CHCl}_{3}\right)$ with a melting point of $58-60^{\circ} \mathrm{C}$. The IR spectrum showed absorption bands at $3360 \mathrm{~cm}^{-1}, 2916 \mathrm{~cm}^{-1}$, and $1454 \mathrm{~cm}^{-1}$. Its molecular formula was determined as $\mathrm{C}_{11} \mathrm{H}_{14} \mathrm{O}_{2}$ by HRESIMS ( $\mathrm{m} / \mathrm{z} 201.0921[\mathrm{M}+\mathrm{Na}]^{+}$; calcd. for $\mathrm{C}_{11} \mathrm{H}_{14} \mathrm{NaO}_{2}, 201.0892$ ), indicating the presence of five degrees of unsaturation in the molecule. The complete assignment of all the protons and carbons was accomplished by
DEPT, HMQC, COSY, and HMBC experiments as shown in Table 1 and Figure 1. The DEPT experiment and the molecular formula indicated the presence of three methylenes, seven methines, and a quaternary carbon. The presence of the benzyl group was suggested by the COSY correlations (bold line in Fig. $1)$ and the HMBC correlations (H-1'/C-1", $\mathrm{H}-1^{\prime} / \mathrm{C}-2^{\prime \prime}, \mathrm{H}-2^{\prime \prime} / \mathrm{C}-1^{\prime}$, $\mathrm{H}-2^{\prime \prime} / \mathrm{C}-1^{\prime \prime}, \mathrm{H}-2^{\prime \prime} / \mathrm{C}-3^{\prime \prime}, \mathrm{H}-2^{\prime \prime} / \mathrm{C}-4^{\prime \prime}, \mathrm{H}-3^{\prime \prime} / \mathrm{C}-2^{\prime \prime}, \mathrm{H}-3^{\prime \prime} / \mathrm{C}-4^{\prime \prime}, \mathrm{H}-$ $\left.4^{\prime \prime} / \mathrm{C}-1^{\prime \prime}, \mathrm{H}-4^{\prime \prime} / \mathrm{C}-2^{\prime \prime}, \mathrm{H}-4^{\prime \prime} / \mathrm{C}-3^{\prime \prime}\right)$. The tetrahydrofuran moiety was elucidated by the COSY correlations $(\mathrm{H}-2 / \mathrm{H}-3, \mathrm{H}-3 / \mathrm{H}-4, \mathrm{H}-$ 4/H-5) and the HMBC correlations (H-2/C-3, H-2/C-4, H-3/C-2, H-3/C-4, H-3/C-5, H-4/C-2, H-4/C-3, H-4/C-5, H-5/C-2, H-5/C$4)$ and the chemical shifts of C-2 ( $\left.\delta_{C} 77.4\right)$ and C-5 $\left(\delta_{C} 60.4\right)$. The connection between the benzyl and tetrahydrofuran moieties was determined by the HMBC correlations $\left(\mathrm{H}-1^{\prime} / \mathrm{C}-2, \mathrm{H}-1^{\prime} / \mathrm{C}-3, \mathrm{H}-\right.$ $\left.2 / \mathrm{C}-1^{\prime}, \mathrm{H}-2 / \mathrm{C}-1^{\prime \prime}, \mathrm{H}-3 / \mathrm{C}-1^{\prime}\right)$. The presence of the hydroxy group at $\mathrm{C}-3$ was suggested by the molecular formula and the chemical shift $\left(\delta_{\mathrm{H}} 3.60\right.$ and $\left.\delta_{\mathrm{C}} 73.2\right)$. All the data allowed us to conclude that 2 was 2-benzyltetrahydrofuran-3-ol. Although NOESY data of $\mathbf{2}$ did not give significant information about its stereochemistry, the NMR data of 2 were completely different from those of $\left(2 R^{*}\right.$, $\left.3 R^{*}\right)$-2-benzyltetrahydrofuran-3-ol that has been reported as a synthetic compound. ${ }^{16,17}$ Therefore, relative configuration of 2 was determined to be $\left(2 S^{*}, 3 R^{*}\right)$.

By comparison of the NMR data and mass spectra of compounds $\mathbf{3}$ and $\mathbf{4}$ with the previous reported papers, they were identified as shown in Figure 1. Compound $\mathbf{3}$ has been reported as an intermediate in the synthesis of cyclopentapyranone, but this is the first report of isolation of $\mathbf{3}$ from a natural source. ${ }^{18}$ Its stereochemistry remains undetermined. Compound $\mathbf{4}$ has been isolated as an inducer of $\mathrm{NAD}(\mathrm{P}) \mathrm{H}$ :quinone oxidoreductase 1 from this mushroom. ${ }^{19}$
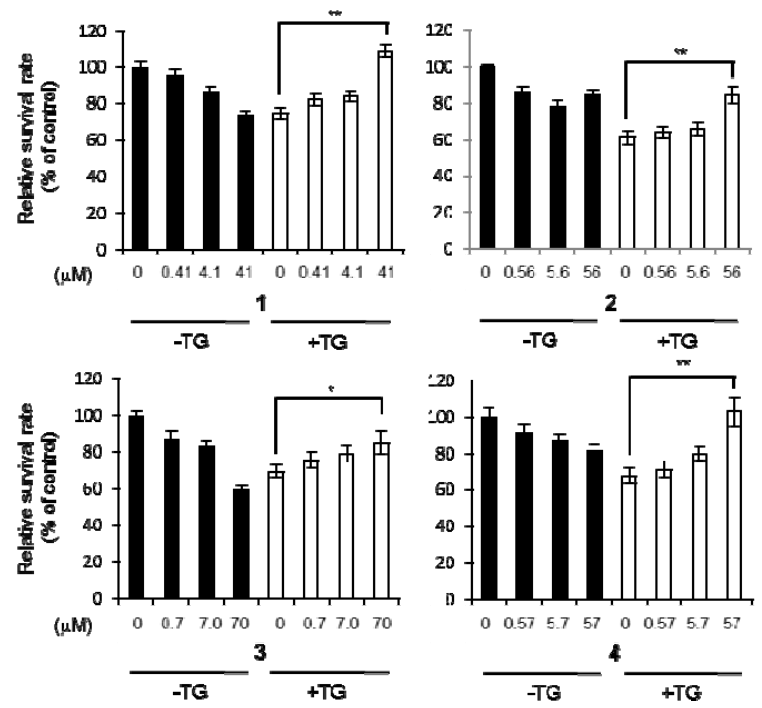

Figure 2. Protective activity of $\mathbf{1}-\mathbf{4}$ against ER stress-dependent cell death. Neuro2a cells were incubated with various concentrations of compounds in the absence or presence of $10 \mathrm{nM}$ thapsigargin (TG) for $24 \mathrm{~h}$. The cell viabilities were analyzed by MTT assay, and the values were represented as the mean $\pm \mathrm{SE}$ of the relative percentage of surviving cells compared with the untreated cells $(\mathrm{n}=10-12)$. (*) $\mathrm{P}<0.01$, Tukey-Kramer multiple comparisons tests.

Compounds 1-4 were subjected to the protective activity assay against ER stress-dependent cell death caused by TM or TG. ${ }^{13}$ ER stress was induced by addition of TM or TG into the culture medium of Neuro2a cells in the presence or absence of each compound. TM is an inhibitor of $N$-linked glycosylation and the formation of $\mathrm{N}$-glycosidic protein-carbohydrate linkages. ${ }^{20}$ TG, an inhibitor of sarcoplasmic/endoplasmic reticulum $\mathrm{Ca}^{2+}$ - 
ATPase, also induces ER stress by disrupting the homeostatic balance of the $\mathrm{Ca}^{2+}$ concentration in the ER. ${ }^{21}$ All the compounds did not show the protective activity against TM-toxicity (data not shown). On the other hand, in the assay using TG, all the compounds showed the protective activity at more than $40 \mu \mathrm{M}$ (Fig. 2).

\section{Acknowledgments}

This work was partially supported by a Grant-in-Aid for Scientific Research on Innovative Areas 'Chemical Biology of Natural Products' from MEXT (Grant Number 24102513).

\section{References and notes}

1. Rao, R. V.; Ellerby, H. M.; Bredesen, D. E., Cell Death Differ., 2004, 11, 372-380.

2. Breckenridge, D. G.; Germain, M.; Mathai, J. P.; Nguyen, M.; Shore, G. C. Oncogene 2003, 22, 8608-8618.

3. Lindholm, D.; Wootz, H.; Korhonen, L. Cell Death Differ. 2006, 13, 385-392.

4. Katayama, T.; Imaizumi, K.; Sato, N.; Miyoshi, K.; Kudo, T.; Hitomi, J.; Morihara, T.; Yoneda, T.; Gomi, F.; Mori, Y.; Nakano, Y.; Takeda, J.; Tsuda, T.; Itoyama, Y.; Murayama, O.; Takashima, A.; St George-Hyslop, P.; Takeda, M.; Tohyama, M. Nat. Cell. Biol. 1999, 1, 479-485.

5. Tamatani, M.; Matsuyama, T.; Yamaguchi, A.; Mitsuda, N.; Tsukamoto, Y.; Taniguchi, M.; Che, Y. H.; Ozawa, K.; Hori, O.; Nishimura, H.; Yamashita, A.; Okabe, M.; Yanagi, H.; Stern, D. M.; Ogawa, S.; Tohyama, M. Nat. Med. 2001, 7, 317-323.

6. Yoshida, H. FEBS J. 2007, 274, 630-658.

7. Nagai, K.; Chiba, A.; Nishino, T.; Kubota, T.; Kawagishi, H. J. Nutr. Biochem. 2006, 17, 525-530.

8. Ueda, K.; Tsujimori, M.; Kodani, S.; Chiba, A.; Kubo, M.; Masuno, K.; Sekiya, A.; Nagai, K.; Kawagishi, H. Bioorg. Med. Chem. 2008, 16, 9467-9470.

9. Ueda, K.; Kodani, S.; Kubo, M.; Masuno, K.; Sekiya, A.; Nagai, K.; Kawagishi, H. Biosci. Biotechnol. Biochem. 2009, 73, 19081910.

10. Choi, J.-H.; Maeda, K.; Nagai, K.; Harada, E.; Kawada, M.; Hirai, H.; Kawagishi, H. Org. Lett. 2010, 12, 5012-5015.

11. Choi, J.-H.; Ozawa, N.; Yamakawa, Y.; Nagai, K.; Hirai, H.; Kawagishi, H. Tetrahedron, 2011, 67, 6649-6653.

12. Choi, J.-H.; Horikawa, M.; Okumura, H.; Kodani, S.; Nagai, K.; Hashizume, D.; Koshino, H.; Kawagishi, H. Tetrahedron, 2009, $65,221-224$.

13. Choi, J.-H.; Suzuki, T.; Okumura, H.; Noguchi, K.; Kondo, M.; Nagai, K.; Hirai, H.; Kawagishi, H. J. Nat. Prod. 2014, 77, 1729 1733.

14. The material, mature fruiting bodies of M. aitchisonii were collected at Narusawa village, Yamanashi Prefecture in Japan, in August 2006. The fresh fruiting bodies of M. aitchisonii $(13.0 \mathrm{~kg})$ were extracted with EtOH $(21 \mathrm{~L}$, three times) and then acetone $(10$ $\mathrm{L}$, once). After the solutions had been combined and concentrated under reduced pressure, the concentrate was partitioned between $\mathrm{CH}_{2} \mathrm{Cl}_{2}$ and $\mathrm{H}_{2} \mathrm{O}$ and then between EtOAc and $\mathrm{H}_{2} \mathrm{O}$. The $\mathrm{CH}_{2} \mathrm{Cl}_{2-}$ soluble part $(73.6 \mathrm{~g})$ was fractionated by silica gel flash column chromatography (hexane/ $\mathrm{CH}_{2} \mathrm{Cl}_{2}$ 7:3, hexane/EtOAc 9:1, 5:5, $\mathrm{CH}_{2} \mathrm{Cl}_{2} / \mathrm{MeOH} 8: 2,5: 5,0: 10,2 \mathrm{~L}$ each) to obtain 25 fractions (fractions 1-25), and fraction 19 (6.9 g) was further separated by silica gel flash column chromatography $\left(\mathrm{CH}_{2} \mathrm{Cl}_{2} /\right.$ acetone $9: 1,7: 3$, 3:7, acetone/MeOH 5:5, and $\mathrm{MeOH}, 1 \mathrm{~L}$ each) and 24 fractions were obtained (fractions 19-1 to 19-24). Fraction 19-15 (751 mg) was separated by silica gel flash column chromatography $\left(\mathrm{CH}_{2} \mathrm{Cl}_{2}\right.$, $\mathrm{CH}_{2} \mathrm{Cl}_{2} / \mathrm{MeOH}$ 99:1, 95:5, 9:1, 1:1, and $\mathrm{MeOH}, 1 \mathrm{~L}$ each) to obtain 11 fractions (fractions 19-15-1 to 19-15-11), and then fraction 19-15-6 (92.7 mg) was further separated by normal-phase HPLC (Senshu Pak AQ, $\mathrm{CHCl}_{3} / \mathrm{MeOH}$ 98:2) to obtain 15 fractions (fractions 19-15-6-1 to 19-15-6-15). Fraction 19-15-6-12 $(5.6 \mathrm{mg}$ ) was separated by reverse-phase HPLC (Develosil C30UG-5, 30\% MeOH) to afford compound $3(1.7 \mathrm{mg})$. Fraction 7 $(13.1 \mathrm{~g})$ was separated by silica gel flash column chromatography $\left(\mathrm{CH}_{2} \mathrm{Cl}_{2}, \mathrm{CH}_{2} \mathrm{Cl}_{2} / \mathrm{MeOH}\right.$ 99:1, 98:2, 95:5, 5:5 and $\mathrm{MeOH}, 1 \mathrm{~L}$ each), and 10 fractions were obtained (fractions 7-1 to 7-10).
Compound 1 (3.0 mg) was purified by normal-phase HPLC (Senshu Pak AQ, hexane/ $\left.\mathrm{CHCl}_{3} 1: 1\right)$ from fraction 7-2 (51 mg). Fraction $18(374 \mathrm{mg})$ was separated by preparative silica TLC $\left(\mathrm{CH}_{2} \mathrm{Cl}_{2} / \mathrm{MeOH}\right.$ 9:1) to obtain 6 fractions (fractions 18-1 to 18-6) and then fraction 18-5 $(72 \mathrm{mg})$ was further separated by preparative ODS TLC $(90 \% \mathrm{MeOH})$ to afford compound 4 (15.2 $\mathrm{mg})$. Similarly, the EtOAc-soluble part $(25.0 \mathrm{~g})$ was separated by silica gel flash column chromatography $\left(\mathrm{CH}_{2} \mathrm{Cl}_{2}, \mathrm{CH}_{2} \mathrm{Cl}_{2} / \mathrm{MeOH}\right.$ 9:1, 7:3, 5:5, and $\mathrm{MeOH}, 1 \mathrm{~L}$ each), and 10 fractions were obtained (fractions 1 to 10). Fraction $7(58.7 \mathrm{mg}$ ) was further separated by normal-phase HPLC (Senshu Pak AQ, hexane/ $\mathrm{CHCl}_{3}$ 96:4) to afford compound 2 ( $2.5 \mathrm{mg})$

15. ${ }^{1} \mathrm{H}$ NMR spectra (one- and two-dimensional) were recorded on a Jeol lambda-500 spectrometer at $500 \mathrm{MHz}$, while ${ }^{13} \mathrm{C}$ NMR spectra were recorded on the same instrument at $125 \mathrm{MHz}$. The HRESIMS spectra were measured on a JMS-T100LC mass spectrometer. A Jasco grating infrared spectrophotometer was used to record the IR spectra. The specific rotation values were measured by using a Jasco DIP-1000 polarimeter. Melting points were measured on a J-Science RFS-10 hot stage microscope. HPLC separations were performed with a Jasco Gulliver system using a reverse-phase HPLC column (Develosil C30-UG-5, Nomura chemical, Japan) and a normal-phase HPLC column (Senshu Pak AQ, Senshu scientific Co., Ltd., Japan). Silica gel plate (Merck F254), ODS gel plate (Merck F254) and silica gel 60 $\mathrm{N}$ (Kanto Chemical, Japan) were used for analytical TLC and for flash column chromatography, respectively.

16. Bach, T. Liebigs Ann. 1995, 1995, 1045-1053.

17. Compound 2: ${ }^{13} \mathrm{C}$ NMR $\left(\mathrm{CDCl}_{3}\right) ; \delta \mathrm{c} 75.2(\mathrm{C}-2), 74.0(\mathrm{C}-3), 33.1$ (C-4), 61.5 (C-5), 38.4 (C-1'), 138.1 (C-1"'), 129.3 (C-2", C-6"), $128.7 \quad\left(\mathrm{C}-3^{\prime \prime}, \quad \mathrm{C}-5^{\prime \prime}\right), \quad 126.6 \quad\left(\mathrm{C}-4^{\prime \prime}\right), \quad\left(2 R^{*}, \quad 3 R^{*}\right)-2-$ benzyltetrahydrofuran-3-ol: ${ }^{13} \mathrm{C}$ NMR $\left(\mathrm{CDCl}_{3}\right) ; \delta \mathrm{c} 83.9(\mathrm{C}-2)$, 72.0 (C-3), 35.1 (C-4), 65.7 (C-5), 35.5 (C-1'), 138.6 (C-1"), 129.1 (C-2", C-6"), 128.4 (C-3", C-5"), 126.2 (C-4").

18. Ohba, M.; Haneishi, T.; Fujii, T. Chem. Pharm. Bull. 1996, 44, 525-529.

19. Kokubo, T.; Taniguchi, Y.; Kanayama, M.; Shimura, M.; Konishi, Y.; Kawagishi, H.; Yamamoto, M.; Shindo, K.; Yoshida, A. Food Chem. 2011, 129, 92-99.

20. Mahoney, W. C.; Duksin, D. J. Biol. Chem. 1979, 254, 6572-6576.

21. Hitomi, J.; Katayama, T.; Taniguchi, M.; Honda, A.; Imaizumi, K.; Tohyama, M. Neurosci. Lett. 2004, 357, 127-130. 